\title{
Water Transport in Lower Hillsborough Bay, Florida, 1995-96
}

By Victor A. Levesque and K.M. Hammett

U.S. Geological Survey

Open-File Report 97-416

Prepared in cooperation with the SOUTHWEST FLORIDA WATER MANAGEMENT DISTRICT

Tallahassee, Florida 1997

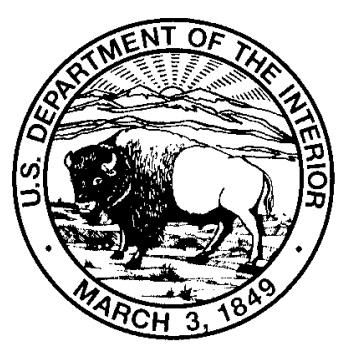




\title{
U.S. DEPARTMENT OF THE INTERIOR \\ BRUCE BABBITT, Secretary
}

\author{
U.S. GEOLOGICAL SURVEY \\ Gordon P. Eaton, Director
}

Any use of trade, product, or firm names in this publication is for descriptive purposes only and does not imply endorsement by the U.S. Geological Survey.

For additional information write to:

District Chief

U.S. Geological Survey

Suite 3015

227 N. Bronough Street

Tallahassee, FL 32301
Copies of this report can be purchased from:

U.S. Geological Survey

Branch of Information Services

Box 25286

Denver, CO 80225-0286

Phone: 800-USA-MAPS 


\section{CONTENTS}

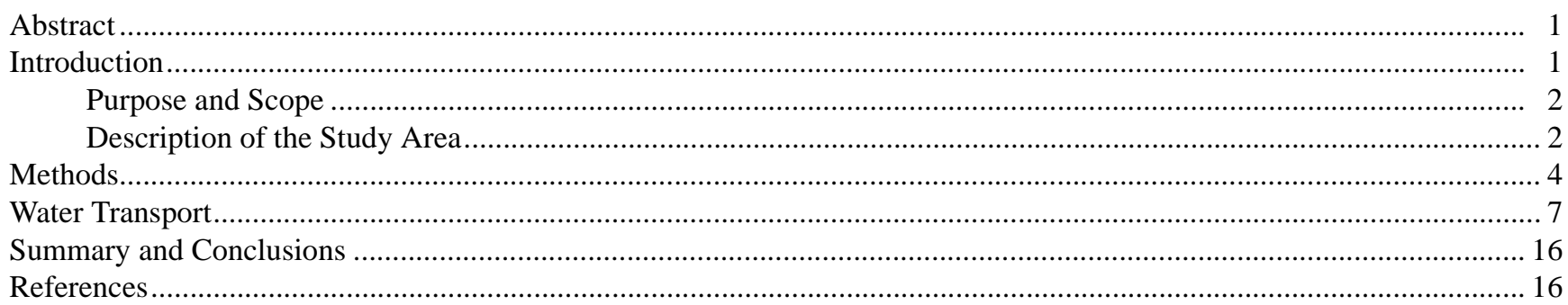

\section{Figures}

1. Map showing location of Hillsborough Bay, Florida

2. Diagram showing terminology used in discussion of acoustic Doppler current profiler measurements and water transport 5.

3. Map showing area of routine measurements.

4-6. Diagrams showing water-transport vectors along the outer transect of the routine measurement area during

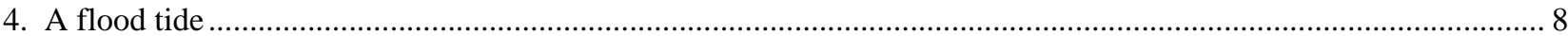

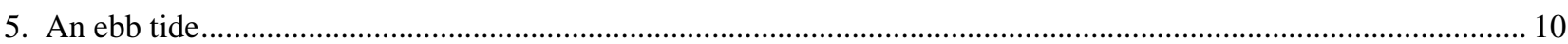

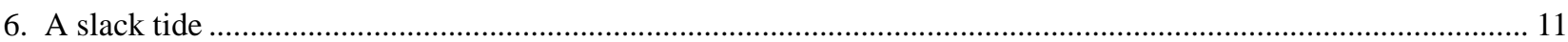

7-9. Diagrams showing water-transport vectors along the inner transect of the routine measurement area during

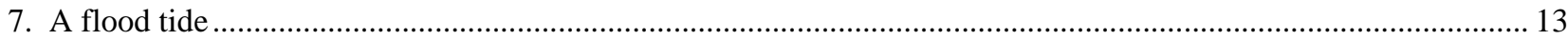

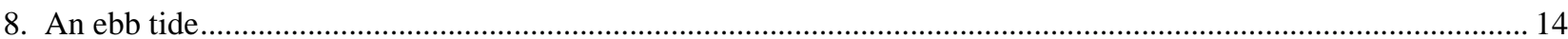

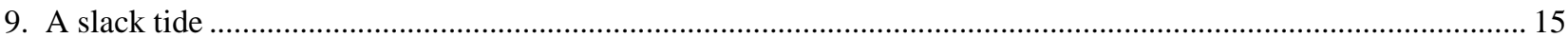

\section{Tables}

1. Physical characteristics of Hillsborough Bay and Tampa Bay ............................................................................ 4

2. Physical characteristics of the routine measurement area and Hillsborough Bay ....................................................... 7

3. Dates, times, and types of water-transport measurements that were made as part of routine data collection .................... 7 


\section{Conversion Factors, Vertical Datum, and Acronym}

\begin{tabular}{rll}
\hline Multiply inch-pound unit & \multicolumn{1}{c}{ By } & To obtain \\
\hline foot $(\mathrm{ft})$ & 0.3048 & meter \\
square mile $\left(\mathrm{mi}^{2}\right)$ & 2.590 & square kilometer \\
foot cubic $\left(\mathrm{ft}^{3}\right)$ & 0.02832 & cubic meter \\
cubic foot per second $\left(\mathrm{ft}^{3} / \mathrm{s}\right)$ & 0.02832 & cubic meter per second \\
million gallons $(\mathrm{gal})$ & $3.785 \times 10^{3}$ & cubic meter \\
\hline
\end{tabular}

Sea level: In this report "sea level" refers to the National Geodetic Vertical Datum of 1929 (NGVD of 1929)—a geodetic datum derived from a general adjustment of the first-order level nets of the United States and Canada, formerly called Sea Level Datum of 1929.

$\mathrm{ADCP}=$ accoustic Doppler current profiler 


\title{
Water Transport in Lower Hillsborough Bay, Florida, 1995-96
}

\author{
By Victor A. Levesque and K.M. Hammett
}

\section{Abstract}

Hillsborough Bay is a subembayment of Tampa Bay on the west-central coast of Florida. Beginning in December 1994, a series of reconnaissance measurements were made to define the probable maximum extent of the area where it could be possible to discern water transport associated with power station withdrawals/discharges. Routine field measurements in 1995-96 confirmed many conclusions previously derived from hydrodynamic models, but also provided much greater detail about the characteristics of water transport. Tidal action is the dominant force affecting water transport in lower Hillsborough Bay. The shipping channel that runs through the center of the estuary is a major conduit for water transport during flood and ebb tides. About one-third of the water transport for the southern segments of the routine measurement area moves through the shipping channel. Except during slack tide, water transport through the shipping channel is at least an order of magnitude greater than water transport for cooling-water withdrawals or discharges and, therefore, withdrawals or discharges at the Big Bend power station are unlikely to affect water-transport characteristics west of the main shipping channel. An east-west shipping channel, spoil islands, and a circulation-inducing cut interact to affect transport along the northern part of the routine measurement area. Along the southern part of the measurement area, shallower water causes transport to be more susceptible to effects from wind and bottom friction. Even when all four units of the Big Bend power station are operating, the effects of tide cause more than four times the volume of water used for power station cooling to move into and out of the routine measurement area. With each tide reversal, more than 25 times as much water enters or leaves Hillsborough Bay and more than 200 times as much water enters or leaves Tampa Bay than is circulated through the power station.

\section{INTRODUCTION}

Water transport is defined as a directional volume of flow per unit of time. Measurements of water transport in estuarine systems have traditionally required large financial and personnel commitments. Consequently, much of the existing information about hydrodynamic characteristics in large estuaries is derived from computer models that were calibrated and verified using stage and velocity data from a limited number of sites. Characteristics of water transport, circulation, and flushing in Hillsborough Bay and Tampa Bay, on the west-central coast of peninsular Florida, previously were described using output from hydrodynamic computer models (Goodwin, 1987, 1991). Hydrodynamic computer models can provide a great deal of valuable information. However, in areas with complex physical features, output from the models is directly related to the spatial resolution or grid size of the model. For example, Goodwin (1991, p. 38) found that by reducing model grid size from 1,500 to 500 feet, to account for multiple spoil islands and shipping channels, computed circulation increased an average of 26 percent in Hillsborough Bay and an adjacent seaward zone. 
The development of boat-mounted ADCP (acoustic Doppler current profiler) technology has provided a method to rapidly measure water transport at wide cross sections in estuaries and tidal rivers. Consequently, it is now possible to measure transport characteristics during a variety of tidal conditions. Factors affecting transport in subareas that previously would have required hydrodynamic models with extremely fine spatial resolution can now be defined from field measurements. ADCP measurements also can be used to check the ability of existing models to replicate field conditions or as input data for a new generation of models.

In the area near the mouth of Hillsborough Bay, multiple physical features exist that could affect watertransport characteristics. The physical features include the intersection of three major shipping channels, old and new spoil islands, circulation-inducing cuts or dredged areas, and the intake and discharge channels for the Big Bend power station of Tampa Electric Company. Goodwin (1991, p. 33) described more than 10 large-scale circulatory patterns resulting from tidal interaction with the physical characteristics of the area.

Recently, the Florida Department of Environmental Protection indicated a concern that withdrawal and discharge of estuarine water for waste-heat transfer at the Big Bend power station could be having a significant effect on water transport in a large area of Tampa Bay. The Big Bend station has a noncontact once-through system in which water is withdrawn from lower Hillsborough Bay and is used to transfer waste heat from the power station. The heated water is then discharged back to lower Hillsborough Bay without making contact with other media. The effect of this withdrawal/discharge relative to other flow characteristics in the area had not been defined. In 1994, the U.S. Geological Survey, in cooperation with the Southwest Florida Water Management District and with the support of Tampa Electric Company, began a study to describe the water-transport characteristics in the area near the mouth of Hillsborough Bay during a variety of tidal conditions and to quantify the magnitude and areal extent of the power station withdrawal/discharge effects relative to other factors affecting transport in the area.

\section{Purpose and Scope}

This report presents results of the study to describe water-transport characteristics during selected tidal phases and to quantify the magnitude and areal extent of power station withdrawal/discharge effects relative to other factors affecting water transport near the mouth of Hillsborough Bay. Reconnaissance data collection began in December 1994 and a series of ADCP field measurements were made to define the probable maximum extent of the area where water transport associated with power station withdrawals/discharges could be discerned. Using ADCP technology, it is possible to show transport characteristics over short periods of time, but it is not possible to show tidally averaged residual circulation patterns. It would be necessary to deploy recording in situ submersible ADCP meters in conjunction with boatmounted ADCP technology to look at longer-term circulation patterns.

Monthly measurements were made to determine whether transport from the Big Bend power station could be detected under a variety of tidal and seasonal conditions. Tidal stage was measured continuously during the year of monthly ADCP measurementsApril 1995 through March 1996. The methods used to measure water transport are outlined, the relative magnitude of various factors affecting transport are discussed, and a series of vector diagrams are presented to describe typical transport characteristics in the study area.

\section{Description of the Study Area}

Tampa Bay, located on the west-central coast of peninsular Florida (fig. 1), is the largest estuary in Florida and has a surface area of more than $345 \mathrm{mi}^{2}$. Hillsborough Bay is a subembayment that represents about 11 percent of the total area of the Tampa Bay estuary. MacDill Air Force Base, the city of Tampa, and the communities of Gibsonton and Apollo Beach are adjacent to Hillsborough Bay. The area has experienced rapid population growth and, consequently, there have been increased needs for all types of infrastructure, including electrical power. 


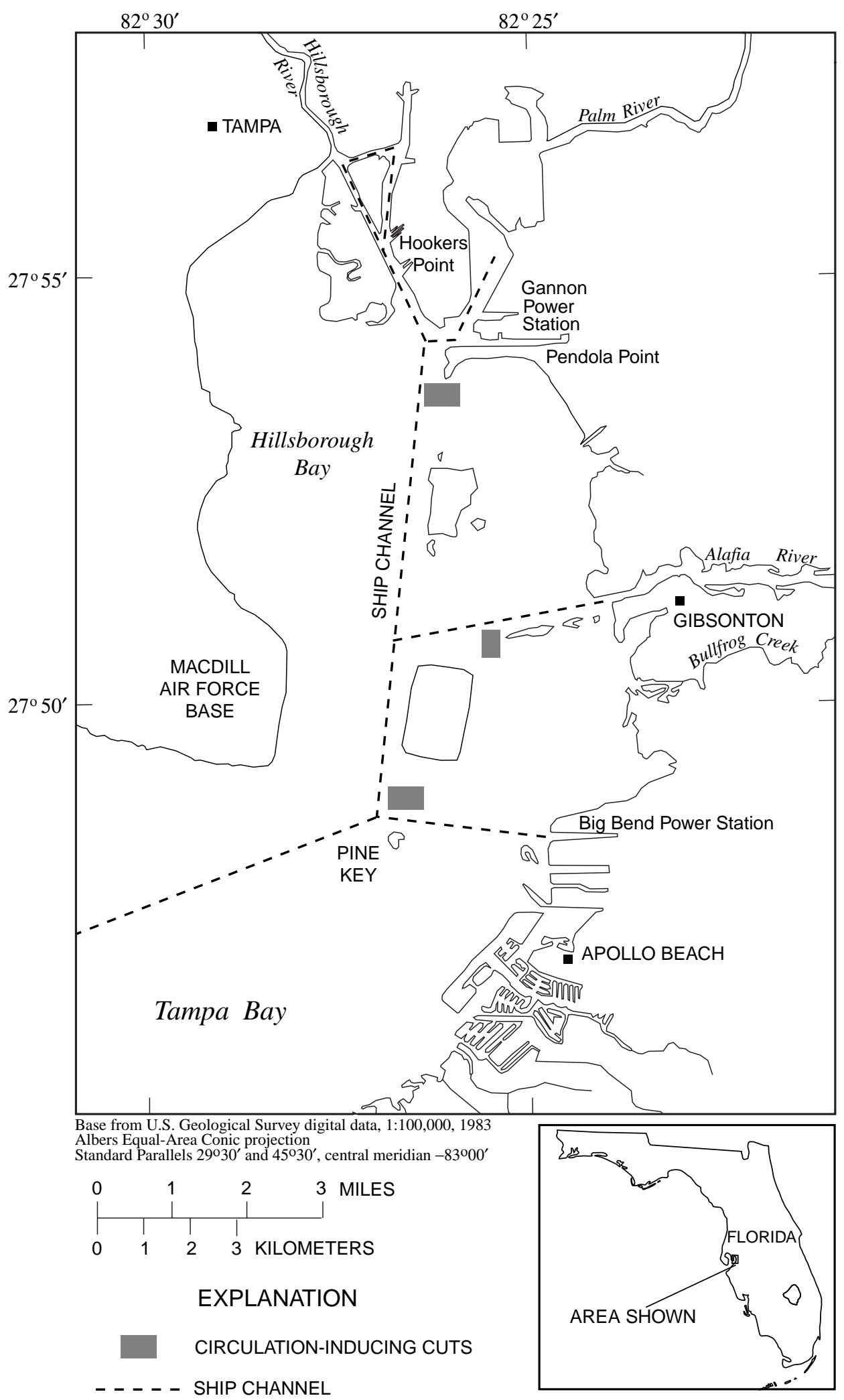

Figure 1. Location of Hillsborough Bay, Florida. (Modified from Goodwin, 1991.) 
The Big Bend power station is north of Apollo Beach, near the mouth of Hillsborough Bay. The first power generating unit at Big Bend began service in 1970 (Tampa Electric Company, 1990). The second, third, and fourth units came into service in 1973, 1976, and 1985, respectively. The four units have a combined output of more than 1,500 megawatts, which is more than half of Tampa Electric Company's total generating capacity. The Big Bend power station along with the Gannon and Hookers Point power stations at the upper end of Hillsborough Bay provide power to more than 450,000 customers. When all four units at Big Bend are operating, about 1,400 Mgal/d (2,160 $\mathrm{ft}^{3} / \mathrm{s}$ ) of water pass through the waste-heat transfer system at the station (written commun., Greg Benton, Tampa Electric Company, 1996).

Goodwin (1987) described physical characteristics of Tampa Bay and Hillsborough Bay for the configuration of shoreline and dredged-and-filled areas that existed in 1985 (table 1). Tidal prism is defined as the volume of water that enters or leaves a tidal water body between high tide and low tide. It is approximately equal to the surface area multiplied by the tidal range between high tide and low tide.

Freshwater inflow, ocean tides, wind, physical geometry, and density differences can affect the movement of water in an estuary; in Hillsborough Bay water movement is dominated by tidal forces. Tides in Hillsborough Bay are mixed, with slack tides (minimum current speed) occurring near high and low water and maximum current speed occurring near mean water level. Tides convey about 2.6 billion $\mathrm{ft}^{3}$ of water across the mouth of Hillsborough Bay during each flood and ebb cycle (table 1). For the physical configuration that existed in 1985 at the Big Bend power station near the mouth of Hillsborough Bay, the tidally induced residual water transport that Goodwin (1991) attributed to the action of flood and ebb tides was about $11,000 \mathrm{ft}^{3} / \mathrm{s}$. In contrast, the water motion that could be attributed to freshwater inflow was less than $1,200 \mathrm{ft}^{3} / \mathrm{s}$, which is an order of magnitude less than the motion resulting from tidal action.

Water transport is expressed in cubic feet per second and can be displayed as a vector, radially oriented to show direction and scaled in length to show magnitude. Goodwin (1991) described circulation patterns in Hillsborough Bay by displaying simulated water-transport vectors that had been averaged over a tidal cycle and concluded that the general circulation pattern was for water to move landward in the deep central part of Hillsborough Bay and to move seaward along the margins of both shores.

\section{METHODS}

A brief summary of the ADCP methods used for this study is provided here. Simpson and Oltmann (1992) provide a detailed description of ADCP methods and applications. As the boat-mounted ADCP traverses a measurement transect, magnitude and direction of velocity is recorded for multiple vertical points. The water column is divided into bins (fig. 2). Velocities within each bin are averaged to produce a single resultant velocity vector, $\overline{\mathrm{u}}$, centered in the bin. Parcels are collections of bins associated with two or more velocity profiles. The water-transport vector, $\mathrm{Q}$, for each parcel is:

$$
\overline{\mathrm{Q}}=\int_{\mathrm{A}}^{\overline{\mathrm{u}} \mathrm{da}}
$$

where:

$$
\begin{aligned}
& \mathrm{A}=\text { area of parcel } \\
& \overline{\mathrm{u}}=\text { velocity vector } \\
& \mathrm{a}=\text { dummy variable of integration. }
\end{aligned}
$$

Table 1. Physical characteristics of Hillsborough Bay and Tampa Bay $\left[\mathrm{mi}^{2}\right.$, square miles; $\mathrm{ft}^{3}$, cubic feet; Mgal, million gallons. From Goodwin, 1991]

\begin{tabular}{lcc}
\hline & Hillsborough Bay & Tampa Bay \\
\hline Approximate surface area $\left(\mathrm{mi}^{2}\right)$ & 36.9 & 347.1 \\
Water volume (billion $\left.\mathrm{ft}^{3}\right)$ & 10.8 & 115.5 \\
Water volume (Mgal) & 80,800 & 863,900 \\
Tidal prism (billion $\mathrm{ft}^{3}$ ) & 2.6 & 21.2 \\
Tidal prism (Mgal) & 19,400 & 158,600 \\
\hline
\end{tabular}



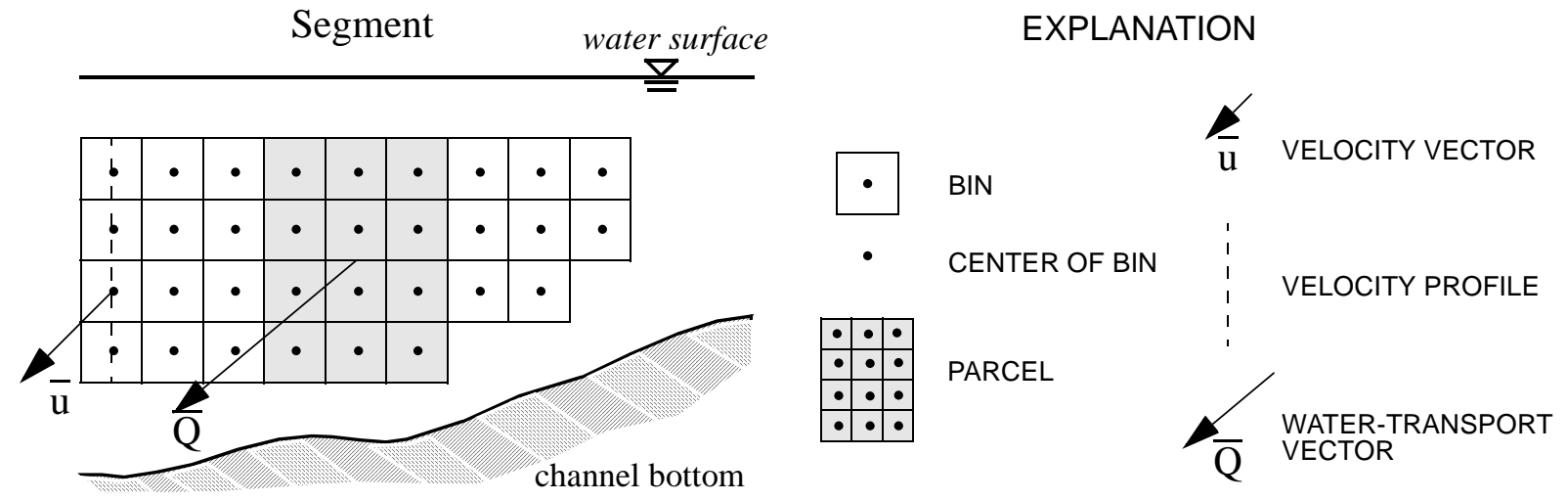

Figure 2. Terminology used in discussion of acoustic Doppler current profiler measurements and water transport.

In December 1994, the U.S. Geological Survey began a series of ADCP reconnaissance measurements to identify cross sections or transects to discern transport associated with withdrawal or discharge from the Big Bend cooling-water process. Reconnaissance measurements were made along a variety of paths, including cross sections at the intake and discharge canals, zigzag paths back and forth across the area immediately west of the Big Bend power station and Apollo Beach, and concentric arcs that had radii increasing with distance from the power station. These reconnaissance measurements revealed complex and dynamic velocity patterns. Not only were there significant differences in transport patterns between flood and ebb conditions, but transport was also unevenly distributed spatially.

The reconnaissance measurements showed that the area where it was possible to discern transport associated with power station withdrawals/discharge was dependent on tide and prevailing wind conditions. Therefore, it was decided to define the probable maximum extent of the area where water-transport effects might be seen and to focus routine data collection to transects within that area. The outer measurement transect of the area of about 4,000 acres that was delineated is shown in figure 3. Physical characteristics of the delineated area are compared to characteristics for Hillsborough Bay in table 2. The area outlined in figure 3 does not represent the area where transport associated with power station withdrawals/discharge are routinely observed. Instead, it represents a perimeter beyond which it would be very unlikely to observe water transport that could be linked to power station operations.
The boat-mounted ADCP cannot be used to measure velocity profiles in water that is less than about $4 \mathrm{ft}$ deep. Consequently, the outer transect of the routine measurement area could not be extended up to the shoreline. Some water transport does occur between the end points of the measurement transects and the shoreline, but the amount of transport is minimal compared to the water transported through the other segments of the transect.

A recording tidal-stage station (fig. 3) was installed in February 1995 and routine data collection began in April 1995. Field-measurement dates were selected so that transport could be measured during a variety of tidal conditions and so that wind effects were minimal to mild. Measurements were made on 15 days between April 1995 and March 1996.

Typically 2 to 6 weeks elapsed between measurements. On 14 of 15 measurement days, all four units at the Big Bend power station were operating; on the remaining day three of the four units were operating. About 1 1/2 hours was needed for each measurement of the outer transect. To traverse a zigzag path or concentric arc within the interior of the outer transect required about 45 minutes to 1 hour. Thus, a day of field measurements usually consisted of two or three outer transect measurements and one or two inner measurements. On most days, a transect across the mouth of Hillsborough Bay from the Big Bend power station to MacDill Air Force Base also was measured. A list of the days when routine measurements were made is provided in table 3 , along with starting and ending times of the measurements, types of measurements, and amount of cooling-water withdrawal/ discharge on those days. 


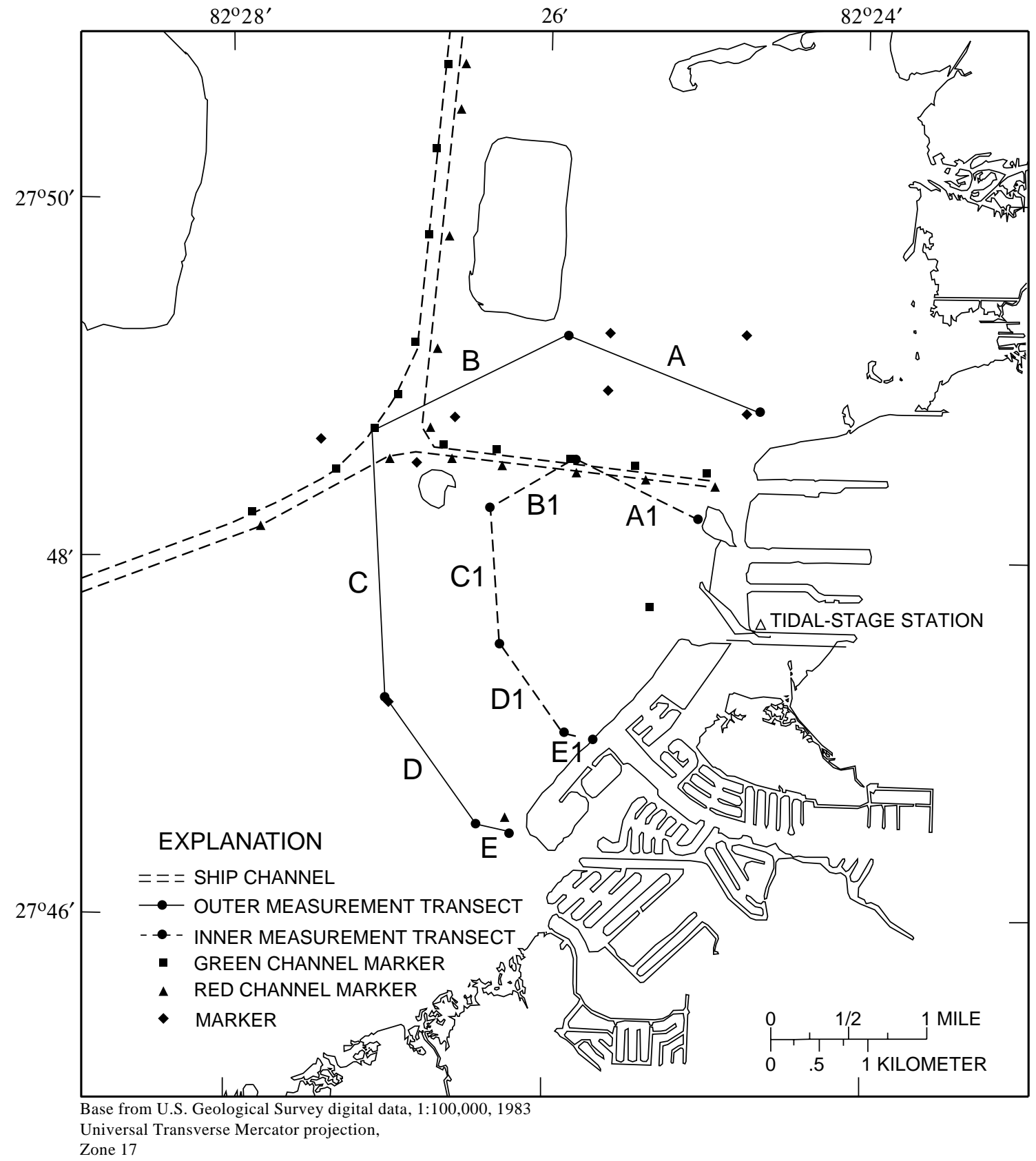

Figure 3. Area of routine measurements. 
Table 2. Physical characteristics of the routine measurement area and Hillsborough Bay $\left[\mathrm{mi}^{2}\right.$, square miles; $\mathrm{ft}^{3}$, cubic feet; Mgal, million gallons $]$

\begin{tabular}{lcc}
\hline & $\begin{array}{c}\text { Routine } \\
\text { measurement } \\
\text { area } \\
\text { (outer transect) }\end{array}$ & $\begin{array}{c}\text { Hillsborough } \\
\text { Bay }\end{array}$ \\
\hline Approximate surface area $\left(\mathrm{mi}^{2}\right.$ ) & 6.25 & 36.9 \\
Water volume (billion $\mathrm{ft}^{3}$ ) & 1.8 & 10.8 \\
Water volume (Mgal) & 13,500 & 80,800 \\
Tidal prism (billion $\mathrm{ft}^{3}$ ) & 0.4 & 2.6 \\
Tidal Prism (Mgal) & 3,000 & 19,400 \\
\hline
\end{tabular}

Table 3. Dates, times, and types of water-transport measurements that were made as part of routine data collection

\begin{tabular}{|c|c|c|c|c|}
\hline Date & Begin time & End time & Types of measurement & $\begin{array}{l}\text { Cooling-water flow } \\
\text { (cubic feet per } \\
\text { second) }{ }^{1}\end{array}$ \\
\hline 4-13-95 & 08:42 & 16:01 & Mouth of Hillsborough Bay, 2 Outer, 2 Inner & 2,147 \\
\hline $5-24-95$ & 09:20 & 18:05 & Mouth of Hillsborough Bay, 2 Outer, 2 Inner & 2,160 \\
\hline $6-07-95$ & 08:16 & $15: 12$ & Mouth of Hillsborough Bay, 2 Outer, 2 Inner & 2,160 \\
\hline 7-11-95 & 10:05 & 11:59 & Equipment Malfunction & 2,081 \\
\hline $7-24-95$ & $06: 51$ & $13: 13$ & 3 Outer, 1 Inner & 2,126 \\
\hline $8-15-95$ & $06: 15$ & $13: 31$ & 4 Outer, 1 Inner & 2,070 \\
\hline $9-26-95$ & 07:35 & $14: 59$ & 4 Outer, 1 Inner & 2,104 \\
\hline $10-19-95$ & 06:41 & $14: 51$ & Mouth of Hillsborough Bay, 3 Outer, 2 Inner & 2,136 \\
\hline $12-01-95$ & 08:07 & $15: 31$ & Mouth of Hillsborough Bay, 3 Outer, 1 Inner & 2,113 \\
\hline $1-10-96$ & $09: 13$ & $15: 09$ & 3 Outer, 1 Inner & 2,101 \\
\hline $1-11-96$ & 09:37 & $15: 38$ & 3 Outer, 2 Inner & 2,160 \\
\hline $1-16-96$ & 09:29 & 16:08 & 4 Outer, 1 Inner & 2,160 \\
\hline $1-30-96$ & 09:42 & $14: 54$ & 3 Outer, 1 Inner & 1,966 \\
\hline $2-26-96$ & 08:38 & $12: 27$ & 3 Inner, 3 Along Shore & 1,604 \\
\hline $3-14-96$ & 09:50 & $15: 17$ & Mouth of Hillsborough Bay, 1 Outer, 1 Inner & 2,160 \\
\hline
\end{tabular}

${ }^{1}$ Cooling-water flow values provided by Tampa Electric Company (written commun., Greg Benton, 1996).

\section{WATER TRANSPORT}

The characteristics of water transport are described by a series of vector diagrams that show the magnitude and direction of water movement along the outer and inner measurement transects during a variety of tidal conditions. Each of the vectors in the diagrams represents a vertical average. In each vector diagram there is a reference vector equivalent to $2,000 \mathrm{ft}^{3} / \mathrm{s}$, which indicates the magnitude of the Big Bend power station withdrawals/discharges, and can be compared to the magnitude and direction of water-transport vectors along the measurement transect. The tidal phase during the measurement is shown as an inset in each plot.
A typical transport pattern along the outer transect of the routine measurement area during a flood tide is shown in figure 4 . The measurement began with segment A (fig. 3) of the transect, proceeded along segments B, C, and D, and ended with segment E. Each of the vectors represents the magnitude and direction of water transport in a separate parcel of the transect. The predominant direction of flow is toward the northeast, which is the direction expected for a flood tide. The sum of the magnitudes of the water-transport vectors was $106,000 \mathrm{ft}^{3} / \mathrm{s}$ for the northern segments ( $A$ and $B$ ) and was $151,000 \mathrm{ft}^{3} / \mathrm{s}$ for the southern segments $(\mathrm{C}, \mathrm{D}$, and $\mathrm{E})$. The greatest amount of transport occurs in the area of the shipping 


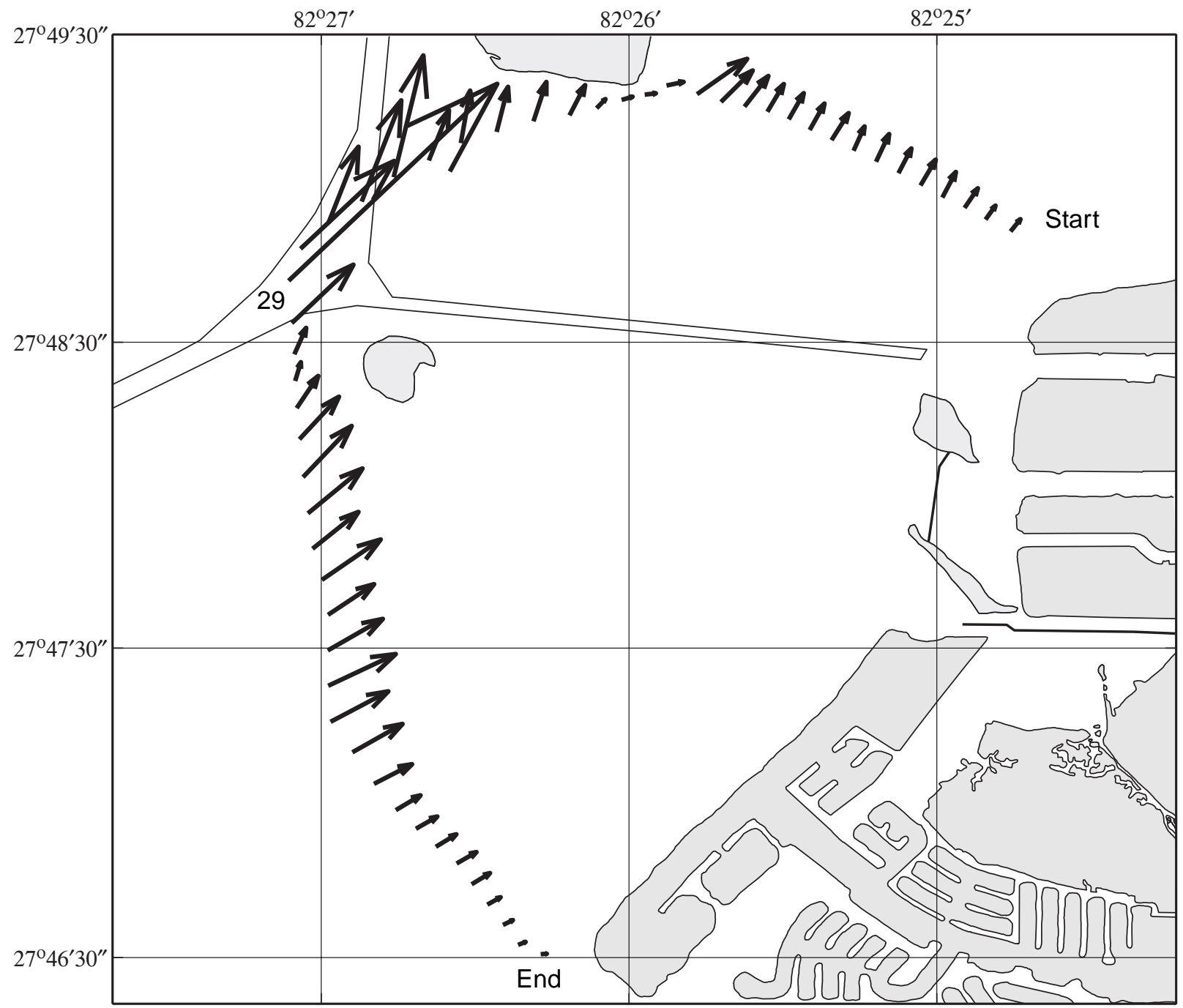

Base from U.S. Geological Survey

Gibsonton, 1:24,000 photorevised 1987

Equidistant Cylindrical Projection

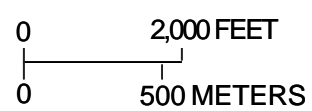

\section{EXPLANATION}

REFERENCE VECTOR--

$\leftarrow \quad$ Length of vector represents 2,000 cubic feet per second

VECTOR NUMBER--

29 Represents 29th parcel from the start of the measurement

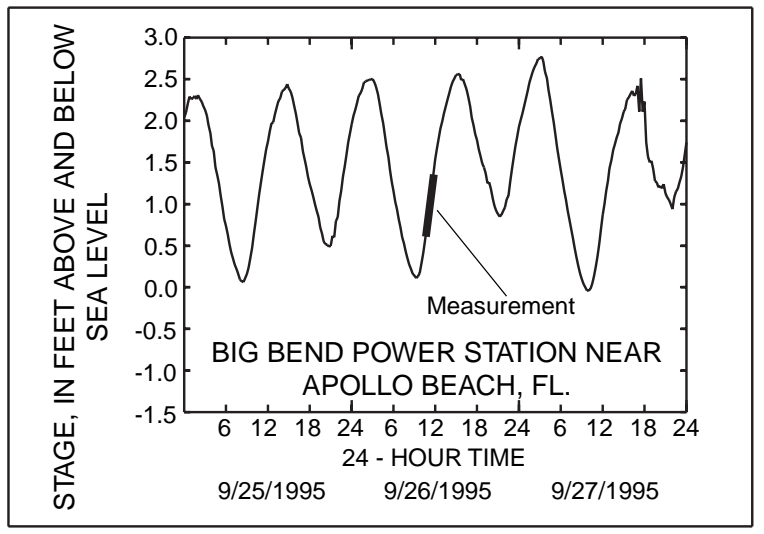

Figure 4. Water-transport vectors along the outer transect of the routine measurement area during a flood tide. 
channel and vector 29, which represents the 29th parcel from the start of the measurement, has a magnitude of almost $28,000 \mathrm{ft}^{3} / \mathrm{s}$. About one-third of the total water transport for segments C, D, and $\mathrm{E}\left(51,000 \mathrm{ft}^{3} / \mathrm{s}\right)$ was in the shipping channel, although the shipping channel represents only about 7 percent of the length of the three segments. The amount of water transport in just the shipping channel during flood tides is an order of magnitude greater than the $2,000 \mathrm{ft}^{3} / \mathrm{s}$ of water circulated through the Big Bend power station. The amount of water transport for segments A and B or for segments $\mathrm{C}, \mathrm{D}$, and $\mathrm{E}$ is two orders of magnitude greater than the $2,000 \mathrm{ft}^{3} / \mathrm{s}$ of water circulated through the power station.

A typical pattern for water-transport vectors during an ebb tide is shown in figure 5. This measurement was made just before low-slack tide, and water velocities would have been approaching a minimum before the tide turned. There was an equipment malfunction at the tidal-stage gage during this measurement and, consequently, the inset in figure 5 showing the tidal stage record was taken from the U.S. Geological Survey continuous-record gaging station at the mouth of the Alafia River near Gibsonton (fig. 1). Comparison of concurrent stage data at the Big Bend power station tidal gage and at the Alafia River near Gibsonton show that tidal phase and amplitude are nearly identical at the two sites. The predominant direction of water movement is toward the southwest, as expected for an ebb tide. The sum of the magnitudes of the water-transport vectors was $46,000 \mathrm{ft}^{3} / \mathrm{s}$ for segments $\mathrm{A}$ and $\mathrm{B}$ and was 66,000 $\mathrm{ft}^{3} / \mathrm{s}$ for segments C, D, and E. The amount of water represented by vector 24 in the area of the shipping channel is about $12,000 \mathrm{ft}^{3} / \mathrm{s}$ and the total amount of water being transported in the shipping channel is $21,000 \mathrm{ft}^{3} / \mathrm{s}$ which is about one-third of the transport for segments $\mathrm{C}, \mathrm{D}$, and $\mathrm{E}$.

Another way of comparing relative magnitudes of water transport is to examine the values of tidal prism presented in tables 1 and 2. A flood tide transports about 21.2 billion $\mathrm{ft}^{3}$ of water into Tampa Bay, about 2.6 billion $\mathrm{ft}^{3}$ of water into Hillsborough Bay and about 0.4 billion $\mathrm{ft}^{3}$ of water into the routine measurement area over a time period of about 6 hours. During the next 6 hours, ebb tide transports the same volumes of water, plus additional water from freshwater inflow, back out of those areas of the estuary. When all four units at the Big Bend power station are operating, about 0.09 billion $\mathrm{ft}^{3}$ of water is circulated through the cooling-water system over a period of 12 hours. Thus, about twice each day, the tide forces more than four times the volume of water used for power station circulation into and out of the routine measurement area. With each turn of the tide, more than 25 times as much water enters or leaves Hillsborough Bay and more than 200 times as much water enters or leaves Tampa Bay as is circulated through the power station.

When tidal currents change direction from flood to ebb or from ebb to flood, there is a time period when tidal velocities approach zero. This time period is referred to as slack tide or slack water. Minimum velocities do not occur simultaneously at all points but, instead, the distribution of velocity in time and space is directly related to tidal stage at various places in the estuary. During slack tide, the effect of withdrawals or discharge for cooling water should be most apparent.

Water-transport vectors during a slack tide on January 16, 1996, are shown in figure 6 . The sum of the magnitudes of the water-transport vectors is about $53,000 \mathrm{ft}^{3} / \mathrm{s}$. Several significant characteristics are apparent from this measurement transect, which began with segment E (fig. 3) and ended with segment A. The greatest amount of transport is again in the area where the shipping channels intersect. The magnitude of water transport represented by vector 27 is 4,100 $\mathrm{ft}^{3} / \mathrm{s}$ which is about twice the amount of water being circulated through the cooling-water system. Although vector 27 is oriented in the direction of transport toward the Big Bend power station, it is also oriented along the east-west shipping channel. Vector 30 , which has about the same magnitude and is also near the intersection of three shipping channels, is oriented perpendicular to the direction of water transported to the power station. Vector 30 is oriented along the direction of the shipping channel that extends into northern Hillsborough Bay and, consequently, it seems likely that the magnitude and direction of both vectors 27 and 30 are predominantly influenced by the shipping channels rather than by the power station.

Another significant feature of the measurement transect begins with vector 40 , which is located near the intersection of segments A and B (fig. 3), and is also close to the eastern edge of the spoil disposal area that is located north of segment B. Vector 30 indicates transport in a northerly direction along the shipping channel. The next vector east of vector 30 also indicates transport in a northerly direction. Vectors 32 through 39, however, are south of a large spoil island and show transport toward the east, indicating that the 


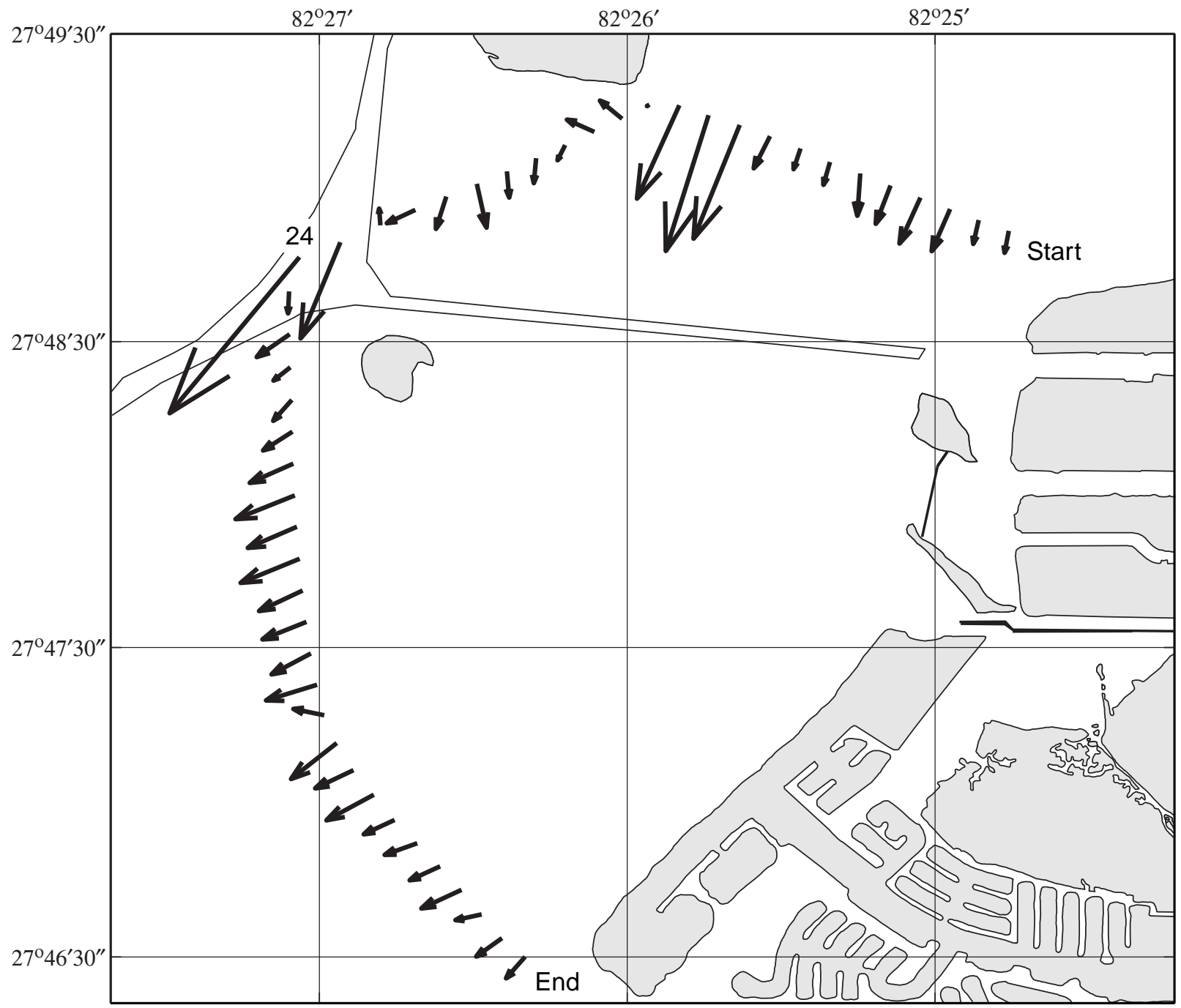

Base from U.S. Geological Survey

Gibsonton, 1:24,000 photorevised 1987

Equidistant Cylindrical Projection

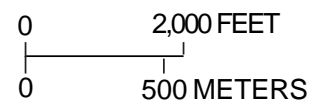

\section{EXPLANATION}

REFERENCE VECTOR--

Length of vector represents

2,000 cubic feet per second

VECTOR NUMBER--

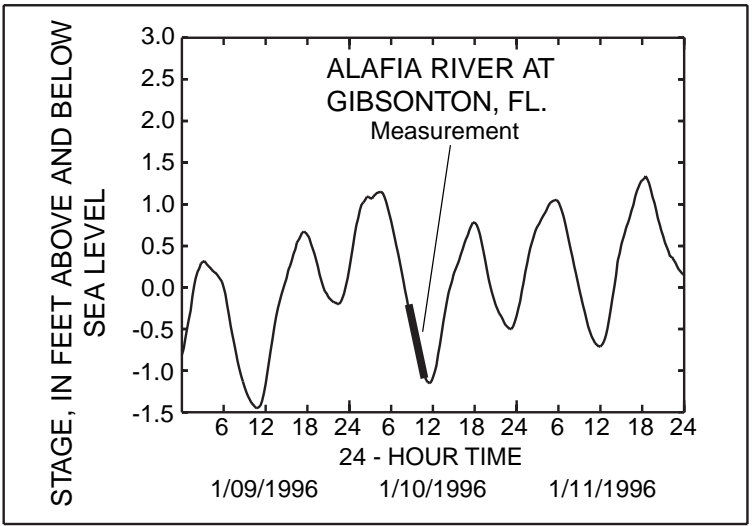

Figure 5. Water-transport vectors along the outer transect of the routine measurement area during an ebb tide. 


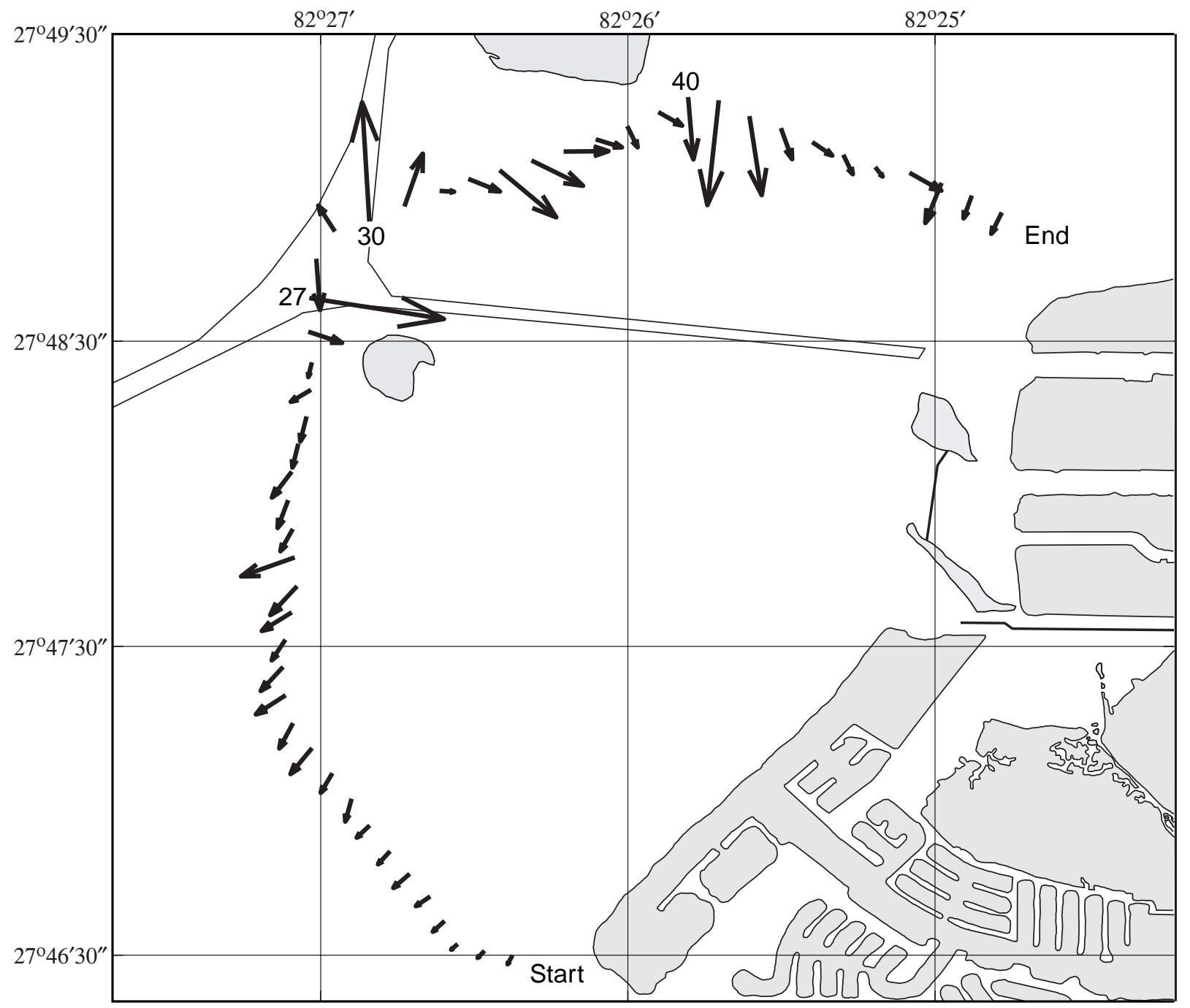

Base from U.S. Geological Survey

Gibsonton, 1:24,000 photorevised 1987

Equidistant Cylindrical Projection

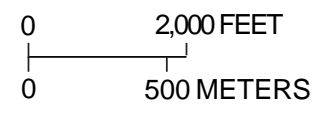

\section{EXPLANATION}

REFERENCE VECTOR--

$\leftarrow \quad$ Length of vector represents

2,000 cubic feet per second

VECTOR NUMBER--

40

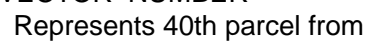
the start of the measurement

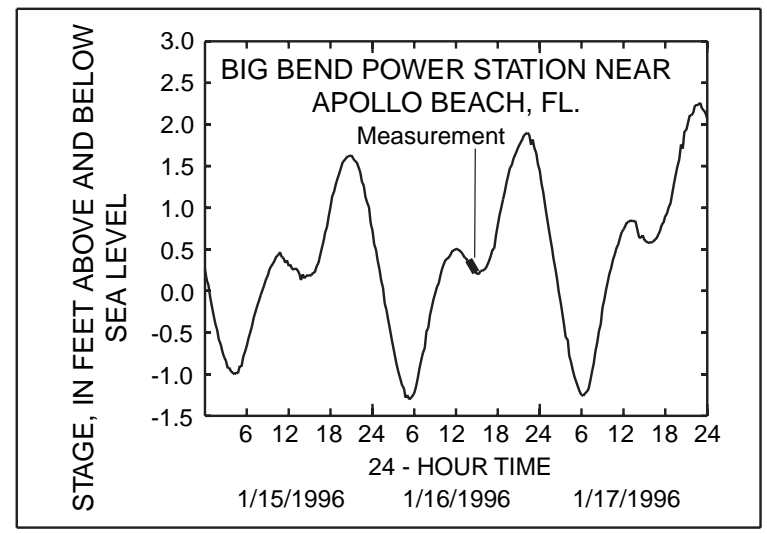

Figure 6. Water-transport vectors along the outer transect of the routine measurement area during a slack tide. 
spoil island is probably affecting transport in that area. Vector 40 is east of the spoil island and that vector, along with vectors 41 and 42 show transport in a southerly direction. Thus, there is a reversal in the direction of transport from the west side of the spoil island to the east side, and this reverse in direction probably results from the presence of the spoil island.

Tidal forces are the dominant factor affecting water-transport characteristics in lower Hillsborough Bay, as illustrated in figures 4, 5, and 6. Field data collected along the outer transect of the routine measurement area indicate that the shipping channel that runs through the center of the estuary is a major conduit for water transport and during flood and ebb tides, about one-third of the transport for the southern segments of the outer measurement transect occurs through the shipping channel. Because of the magnitude of transport in the shipping channel, withdrawals/discharges for the Big Bend power station cooling system are unlikely to affect water-transport patterns west of the main shipping channel. The east-west shipping channel that extends toward the power station also appears to affect water transport, but the effects are complicated by spoil islands adjacent to that channel. The presence of a circulation-inducing cut (fig. 1) just north of the east-west channel (Goodwin, 1991) further complicates the physical geometry and may also affect water transport. Along the southern segments of the outer measurement transect, the water is much shallower and more likely to be affected both by wind and bottom friction and, consequently, it is difficult to identify transport associated with cooling-water withdrawals or discharges except directly adjacent to the intake and outlet channels.

Although several transects were measured within the interior of the routine measurement area, the transects shown in figures 7 through 9 were made along the inner transect shown in figure 3, encompassing segments A1 through E1. This inner transect encloses an area of about 1,900 acres, or about one half of the total routine measurement area. The depths, however, are shallower within the inner transect and, consequently, the volume of water in the inner area is less than one-half of the volume of the outer area.
Typical water-transport vectors along the inner transect during a flood tide are shown in figure 7. The sum of the magnitudes of the water-transport vectors for segments $\mathrm{A} 1$ and $\mathrm{B} 1$ (fig. 3) of this inner transect is about $13,000 \mathrm{ft}^{3} / \mathrm{s}$; for segments $\mathrm{C} 1, \mathrm{D} 1$, and $\mathrm{E} 1$ the sum is about $24,000 \mathrm{ft}^{3} / \mathrm{s}$. The flood tide during which this measurement was made occurred after the neap part of the monthly tidal cycle, whereas the flood tide shown in figure 4 was during the spring part of the cycle. The water transport represented by vector 32 is $1,700 \mathrm{ft}^{3} / \mathrm{s}$. The direction of transport indicated by vector 32 is in the general direction of the east-west shipping channel. However, other vectors along the southern segments of the transect have similar magnitudes and directions, so the influence of the shipping channel is not as apparent as it was in the outer transect. The $2,000 \mathrm{ft}^{3} / \mathrm{s}$ of water passing through the cooling-water system is an order of magnitude less than the sum of the water-transport vectors for this transect.

Typical water-transport vectors along the inner transect during an ebb tide are shown in figure 8 . The sum of the magnitudes of the water-transport vectors for the transect is $46,000 \mathrm{ft}^{3} / \mathrm{s}$. Vector 12 represents about $2,800 \mathrm{ft}^{3} / \mathrm{s}$ and, although it is near the area of the east-west shipping channel, other vectors along the transect have similar magnitudes and directions.

Any effects on water transport resulting from cooling-water withdrawals or discharges should be most apparent during slack tide. Water-transport vectors along the inner transect during a slack tide in February 1996 are shown in figure 9 . The reference vector shows the magnitude of the $2,000 \mathrm{ft}^{3} / \mathrm{s}$ of water circulating through the cooling system relative to transport along the inner transect. The sum of the magnitudes of the water-transport vectors for segments A1 and $\mathrm{B} 1$ is $3,400 \mathrm{ft}^{3} / \mathrm{s}$ and for $\mathrm{C} 1, \mathrm{D} 1$, and $\mathrm{E} 1$ it is 8,000 $\mathrm{ft}^{3} / \mathrm{s}$, the smallest transport shown in any of the figures 4 through 9 . However, there is no obvious transport pattern that can be specifically associated to withdrawals or discharges from the Big Bend power station. 


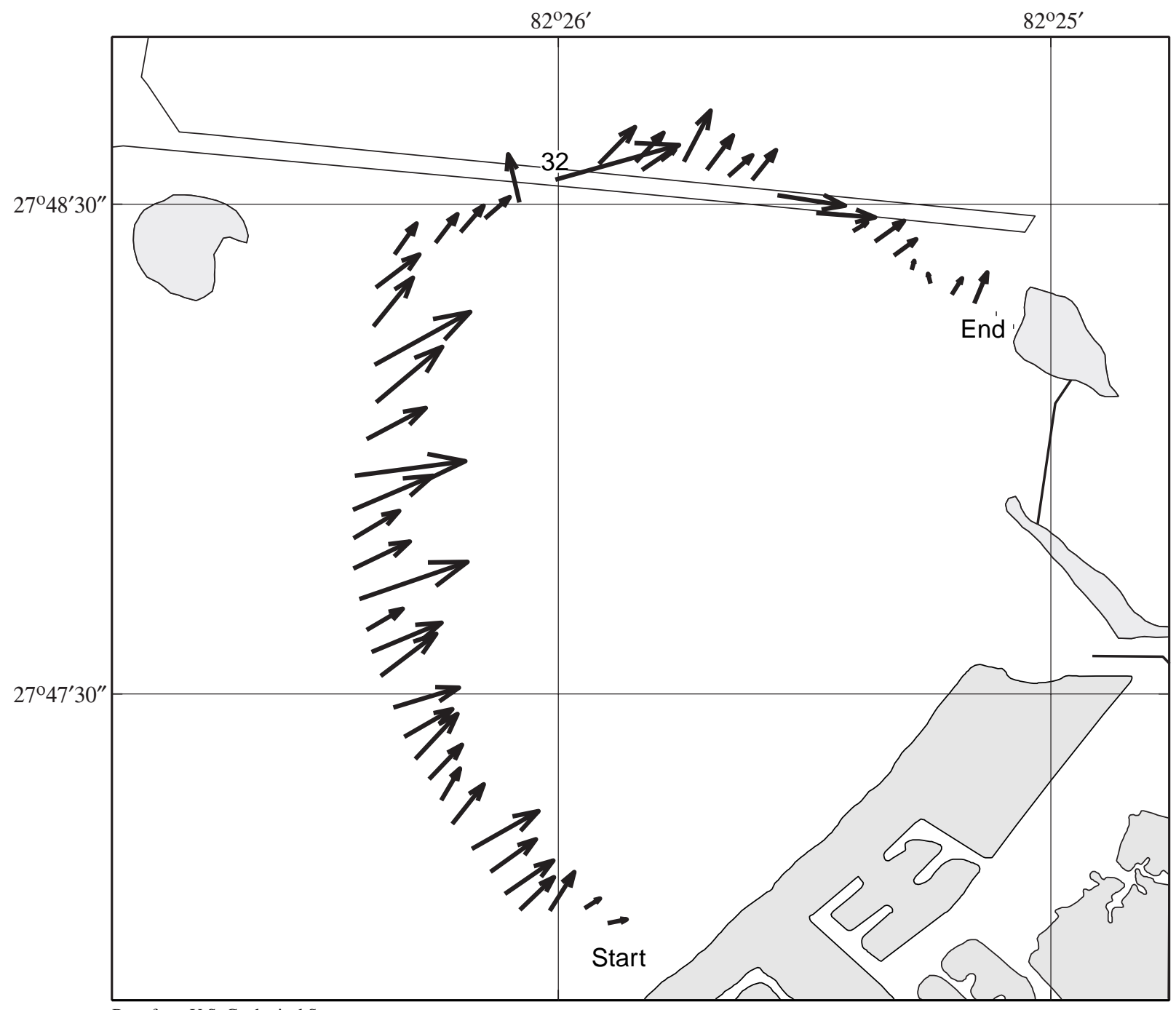

Base from U.S. Geological Survey

Gibsonton, 1:24,000 photorevised 1987

Equidistant Cylindrical Projection

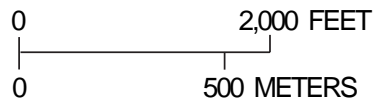

\section{EXPLANATION}
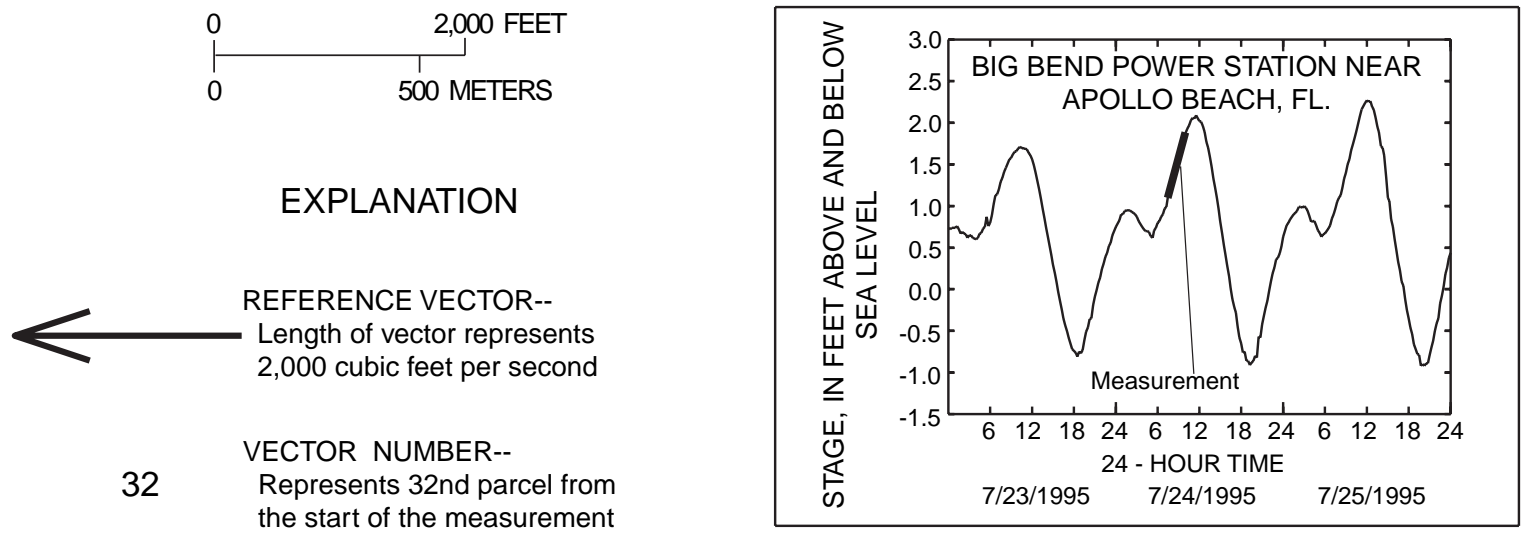

Figure 7. Water-transport vectors along the inner transect of the routine measurement area during a flood tide. 


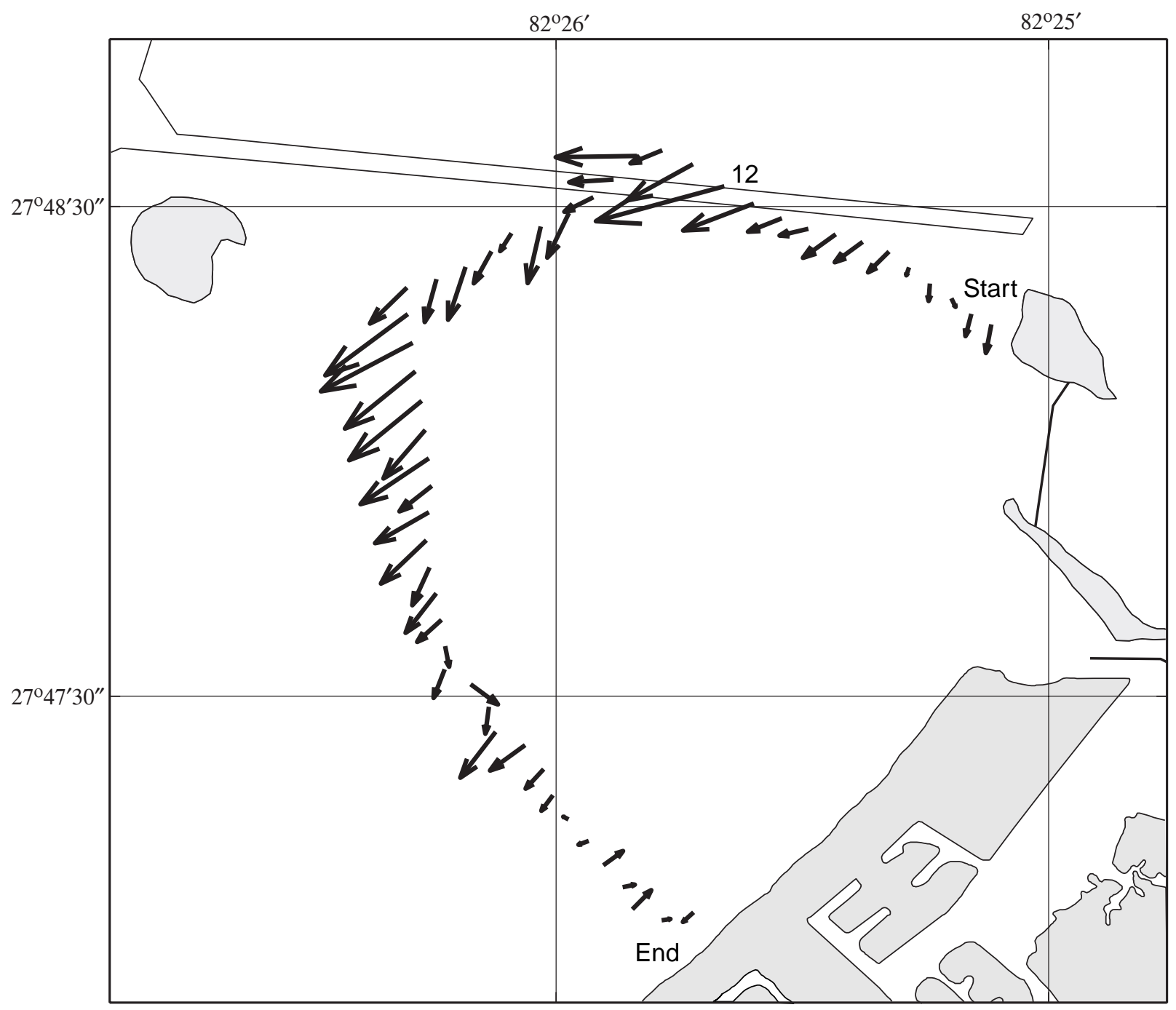

Base from U.S. Geological Survey

Gibsonton, 1:24,000 photorevised 1987

Equidistant Cylindrical Projection

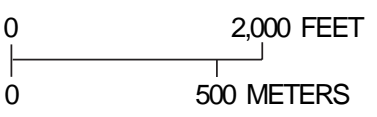

\section{EXPLANATION}
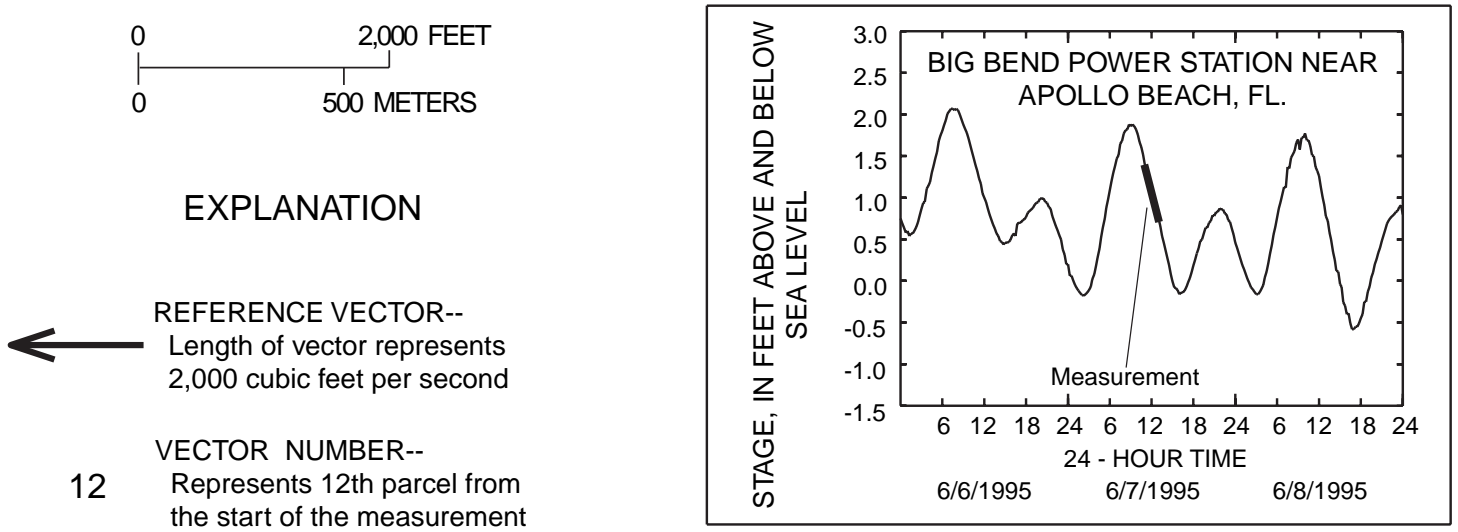

Figure 8. Water-transport vectors along the inner transect of the routine measurement area during an ebb tide. 


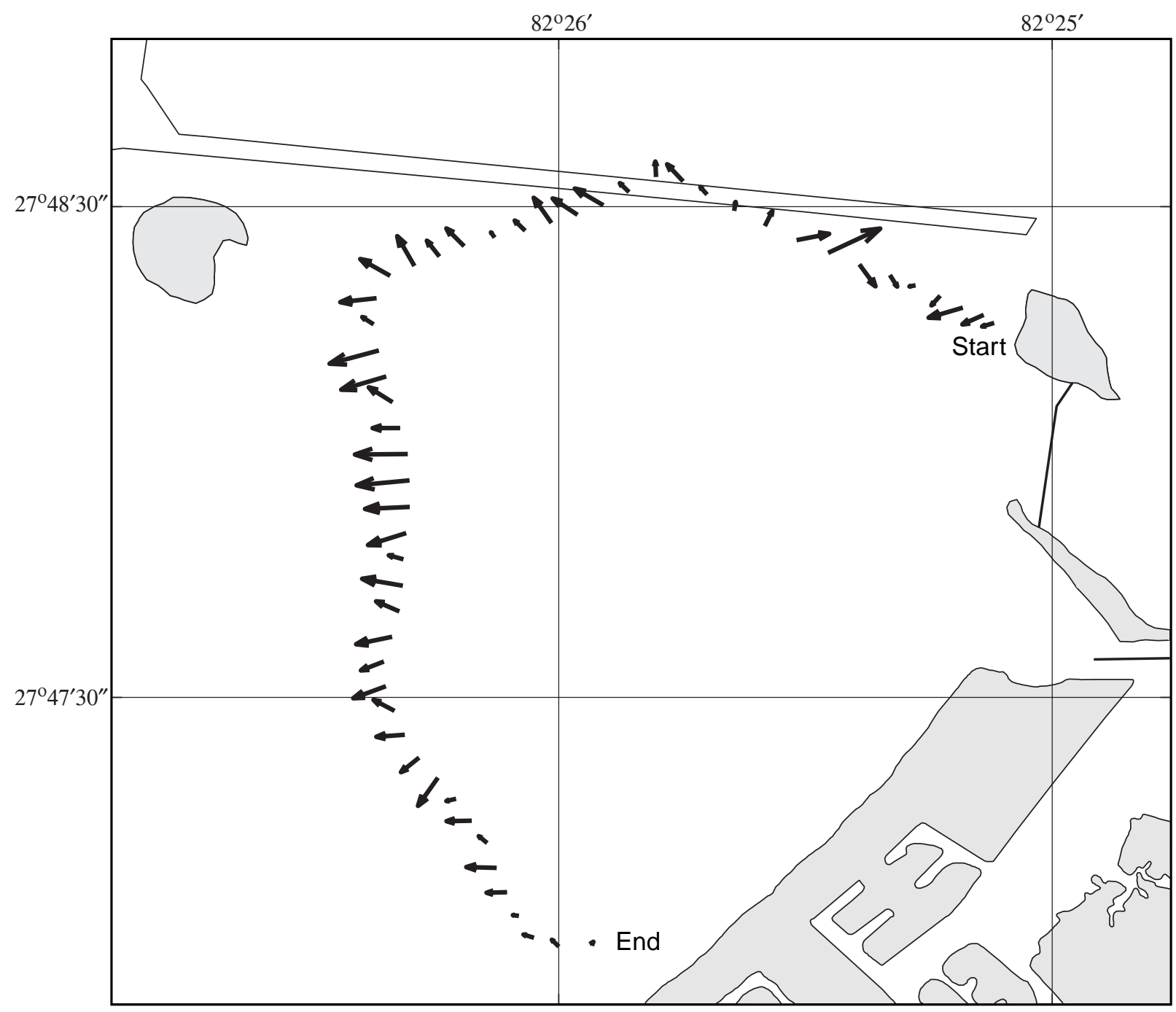

Base from U.S. Geological Survey

Gibsonton, 1:24,000 photorevised 1987

Equidistant Cylindrical Projection

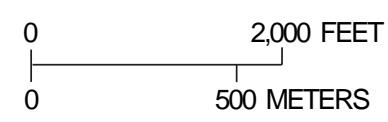

\section{EXPLANATION}
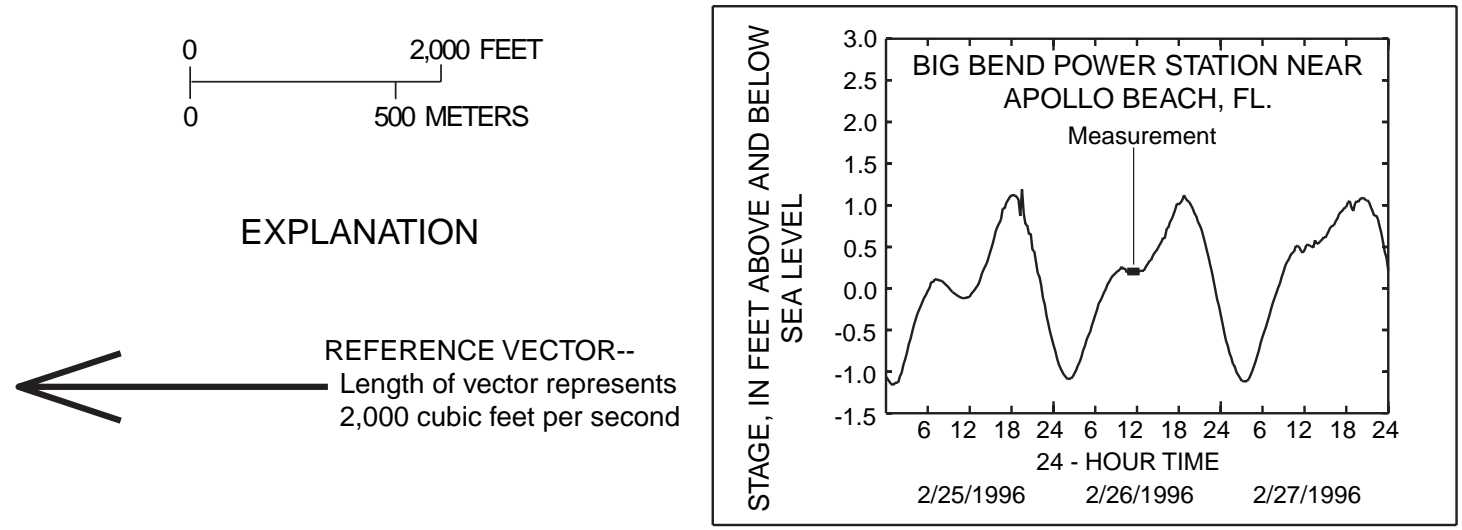

Figure 9. Water-transport vectors along the inner transect of the routine measurement area during a slack tide. 


\section{SUMMARY AND CONCLUSIONS}

Much of the information about water transport in Hillsborough Bay and Tampa Bay has been derived from hydrodynamic models. While output from calibrated hydrodynamic models can provide valuable information, the spatial resolution of the existing models does not allow for evaluation of watertransport effects from many complex or local physical features. Although a numerical model with the needed spatial resolution could be developed, it would be extremely costly to calibrate using field data. The development of boat-mounted acoustic Doppler current profiler technology has made it possible to rapidly measure water transport at wide cross sections in estuaries and tidal rivers under a variety of tidal conditions and to use that field data to describe watertransport characteristics.

The lower part of Hillsborough Bay has multiple physical features that could affect water transport. In addition, there has been some concern that cooling-water withdrawals or discharges for the Big Bend power station, which is near the mouth of the bay, could be having a significant effect on a large area of the estuary. A series of reconnaissance measurements was used to define an area of 4,000 acres outside of which it would be very unlikely to observe water transport that could be linked to power station operations. Measurements were made within this area during a variety of tidal conditions to determine whether there were obvious patterns of transport associated with cooling-water withdrawals or discharges and also to describe the magnitude of cooling-water transport relative to other transport characteristics in the lower part of Hillsborough Bay.

Field measurements confirmed many conclusions previously presented as a result of interpreting output from hydrodynamic models. Tidal action is the dominant force affecting water transport in lower Hillsborough Bay. The shipping channel that runs through the center of the estuary is a major conduit for water transport during flood and ebb tides.
About one-third of the transport across the southern part of the routine measurement area moves through the shipping channel. Except during slack tide, transport in the shipping channel is at least an order of magnitude greater than the transport for cooling-water withdrawals or discharges. Because of the magnitude of transport in the shipping channel, withdrawals or discharges for the Big Bend power station are unlikely to affect water-transport patterns west of the main shipping channel. A second east-west shipping channel, spoil islands, and a circulation-inducing cut all interact to affect transport along the northern part of the routine measurement area. Along the southern part of the routine measurement area, shallower water makes transport across the measurement section more susceptible to effects from wind and bottom friction. Even when all four units of the Big Bend power station are operating, the tide is forcing more than four times the volume of water used for power station cooling into and out of the routine measurement area. With each reversal of the tide, more than 25 times as much water enters or leaves Hillsborough Bay and more than 200 times as much water enters or leaves Tampa Bay than is circulated through the power station.

\section{REFERENCES}

Goodwin, C.R., 1987, Tidal-flow, circulation, and flushing changes caused by dredge and fill in Tampa Bay, Florida: U.S. Geological Survey Water-Supply Paper 2282, $88 \mathrm{p}$.

1991, Tidal-flow, circulation, and flushing changes caused by dredge and fill in Hillsborough Bay, Florida: U.S. Geological Survey Water-Supply Paper 2376, $49 \mathrm{p}$.

Simpson, M.R., and Oltmann, R.N., 1992, Dischargemeasurement system using an acoustic Doppler current profiler with applications to large rivers and estuaries: U.S. Geological Survey Water-Supply Paper 2395, $32 \mathrm{p}$.

Tampa Electric Company, 1990, Tampa Electric Big Bend Station: Tampa Electric Company brochure, 1 sheet. 